\title{
ANALISIS PENGGUNAAN MEDIA PEMBELAJARAN DALAM MENINGKATKAN KEMAMPUAN BERPIKIR KREATIF SISWA
}

\author{
Rohayu' ${ }^{1)}$, Deni Adi Putra ${ }^{2)}$, Kunti Dian Ayu Afiani ${ }^{3)}$ \\ ${ }^{1), 2,3)}$ Universitas Muhammadiyah Surabaya \\ Corresponding author E-mail: rohayutasrif97@gmail.com
}

\begin{abstract}
Abstrak
Kata Kunci:

Media pembelajaran, kemampuan berpikir kreatif siswa

Penelitian ini bertujuan untuk menganalisis penggunaan media pembelajaran dalam meningkatkan kemampuan berpikir kreatif siswa. Metode penelitian yang digunakan dalam penelitian ini adalah metode penelitian Meta-analisis, Objek dalam penelitian ini adalah menggunakan 10 jurnal yang relevan yang variabelnya sesuai dengan judul penelitian. Berdasarkan analisis dan pembahasan yang telah dilakukan melalui review 10 jurnal dapat disimpulkan bahwa penggunaan media dapat meningkatkan kemampuan berpikir kreatif siswa dengan total presentase menacapai $80,74 \%$. Terdapat perbedaan hasil peningkatan kemampuan berpikir kreatif siswa disetiap data penelitian.Hal ini disebabkan oleh berbedaan objek penelitian, pendekatan, prinsip, dan konsep yang digunakan untuk menganalisis permasalahan disetiap penelitiannya berbeda. penggunaan media dalam proses pembelajaran dapat meningkatkan kemampuan berpikir kreatif siswa, oleh karena itu diharapkan guru dapat mengetahui pentingnya penggunaan media dalam proses pembelajaran sehingga guru dapat mengetahui kemampuan berpikir kreatif siswa dalam belajar dan guru akan lebih kreatif dan variatif dalam menggunakan media saat proses pembelajaran.
\end{abstract}

\section{Keyword:}

Learning media, Students' creative thinking skills

\section{Abstract:}

This research aims to analyze the use of instructional media in improving students' creative thinking skills. The methodology used in this research is the meta-analysis research method. The object of this research is 10 relevant journals whose variables are in accordance with the research topic. Based on the analysis and discussion that has been carried out through a review of 10 journals. It can be concluded that the use of media can improve students' creative thinking skills with a total percentage reaching $80.74 \%$. There are differences in the results of increasing students' creative thinking skills in each research data. This is due to the different objects of research, approaches, principles, and concepts used to analyze problems in each different research. The use of media in the learning process can improve students' creative thinking skills. Therefore, it is hoped that the teacher can understand the importance of using media in the learning process so the teacher can find out students' creative thinking skills in learning and teachers will be more creative and varied in using media during the learning process. 


\section{Pendahuluan}

Seiring dengan kemajuan zaman dan semakin berkembangnya ilmu pengetahuan dan teknologi, tantangan masa depan akan selalu berubah dan persaingan akan semakin ketat. Dalam menghadapi tantangan masa depan diperlukan lulusan pendidikan yang terampil dalam segala bidang, dan juga kreatif dalam mengembangkan bidang yang ditekuninya. Dan diwujudkan dalam semua pembelajaran, termasuk matematika. Peraturan Menteri Pendidikan Nasional Nomor 22 Tahun 2016 menyebutkan bahwa mata pelajaran matematika wajib diberikan kepada semua jenjang pendidikan, mulai dari jenjang sekola dasar hingga perguruan tinggi. Hal ini bertujuan untuk memberikan bekal kepada peserta didik dengan kemampuan berpikir logis, analitis,sistematis,kritis, kreatif, serta kemampuan bekerjasama dalam kehidupan sehari-hari.

Pentingnya kreativitas atau kemampuan berpikir kreatif dalam kaitannya dengan upaya peningkatan mutu pendidikan memang sangat logis, sebagaimana dikatakan oleh Costa Berthur dalam Suryadi (2016) bahwa kemampuan berpikir kreatif siswa dianggap sebagai sumber yang amat vital bagi suatu bangsa. Oleh karena itusistem pendidikan (formal, non formal, informal) hendaknya ditujukan untuk mengembangkan kualitas perpikir anak agar dalam proses perkembangan kognitif dan inteligensinya memperoleh peluang secara optimal pula. Kemampuan berpikir kreatif diperlukan untuk mengembangkan ilmu pengetahuan dan teknologi serta menjadi penentu kesuksesan individu dalam menghadapi tantangan kehidupan yang semakin kompleks. Seseorang yang kreatif akan selalu dibutuhkan oleh lingkungannya karena mereka mampu memenuhi kebutuhan lingkungan yang terus berubah seiring dengan perkembangan zaman.

Berdasarkan data PISA pada tahun 2018 lagi-lagi menempatkan siswa Indonesia di jajaran nilai terendah terhadap pengukuran membaca, matematika, dan sains. Pada kategori kemampuan membaca, Indonesia menempati peringkat ke-6 dari bawah (74) dengan skor rata- rata 371. lalu pada kategori matematika, Indonesia berada di peringkat ke-7 dari bawah (73) dengan skor rata-rata 379. Sementara pada kategori kinerja sains, Indonesia berada di peringkat ke-9 dari bawah (71), yakni dengan rata-rata skor 396. Hal tersebut telah membuktikan bahwa prestasi belajar matematika di Indonesia masih sangat rendah, yang disebabkan oleh rendahnya kreativitas dalam proses pembelajaran. Siswono (2008) menyatan bahwa kreativitas merupakan suatu hal yang 
kurang diperhatikan dalam pembelajaran matematika. Selama ini guru hanya mengutamakan logika dan kemampuan proses belajar mengajar di dalam kelas. Selain itu, rendahnya kemampuan berpikir kreatif matematis dapat dilihat dari rendahnya kemampuan siswa dalam memecahkan masalah rutin ataupun nonrutin. Sedangkan merencanakan penyelesaian suatu masalah ditunjukkan dengan mengorganisasikan informasi atau data-data yang ada secara kreatif dengan menggunakan strategi-strategi tertentu untuk menemukan kemungkinan penyelesaian.

Berpikir kreatif merupakan sesuatu kegiatan mental yang digunakan seseorang untuk membangun suatu ide atau gagasan yang "baru" secara fasih dan fleksibel Siswono, (2008). Kreativitas menurut Ghufron dan Risnawati (2011) adalah suatu prestasi dimana peserta didik dapat memecahkan masalah yang jarang orang lain dapat melakukanya, menemukan ideide baru, serta gagasan yang cemerlang. Kreativitas siswa sebagai salah satu kekuatan untuk mencapai keberhasilan dalam proses pembelajaran. Hal ini dikarenakan supaya setiap siswa dapat Siswa dikatakan tidak kreatif jika tidak dapat menunjukkan ketiga karakteristik tersebut dalam komputasi (hitung-menghitung) sehingga kreativitas dianggap bukanlah sesuatu yang penting dalam

mengembangkan diri dalam memecahkan masalah-masalah yang dihadapi pada saat proses pembelajaran.

Siswono dalam Afiani (2017) merumuskan 5 tingkat kemampuan berpikir kreatif siswa antara lain sebagai berikut :

1. Tingkat 4 ( Sangat Kreatif)

Siswa dikatakan sangat kreatif jika mampu menunjukkan karakteristik: Kefasihan, fleksibilitas, dan kebaruan, atau Kebaruan dan fleksibilitas

2. Tingkat 3 (Kreatif)

Siswa dikatakan kreatif jika mampu menunjukkan karakteristik: Kefasihan dan kebaruan, atau Kefasihan dan fleksibilitas

3. Tingkat 2 (Cukup Kreatif)

Siswa dikatakan cukup kreatif jika mampu menunjukkan karakteristik:

Kebaruan, atau Fleksibilitas

4. Tingkat 1 (Kurang Kreatif)

Siswa dikatakan kurang kreatif jika mampu menunjukkan karakteristik kefasihan dalam memecahkan maupun mengajukan masalah

5. Tingkat 0 (Tidak Kreatif) memecahkan maupun mengajukan masalah.

Tingkat kemampuan berpikir kreatif di atas dapat ditentukan dari 3 karakteristik 
tersebut untuk menilai, yaitu kefasihan, fleksibilitas dan kebaruan dalam mengajukan masalah menurut Silver, dalam Siswono (2008: 44). Indikator kefasihan adalah siswa dapat membuat banyak soal atau masalah yang dapat dipecahkan. Indikator fleksibilitas adalah siswa mengajukan soal atau masalah yang mempunyai banyak cara penyelesaian atau menggunakan pendekatan"what if not?" dalam mengajukan masalah. Indikator kebaruan adalah siswa dapat mengajukan soal atau masalah yang berbeda menurut siswa lain.

Guru dituntut untuk kreatif menggunakan dan memanfaatkan media yang tersedia disekolah, atau tidak menutup kemungkinan guru akan mengembangkan media yang disesuaikan dengan tujuan pembelajaran yang diharapkan. Penggunaan media dalam pengajaran di kelas merupakan sebuah kebutuhan yang tidak dapat diabaikan. Hal ini dapat dipahami mengingat proses belajar yang dialami siswa tertumpu pada berbagai kegiatan menambah ilmu dan wawasan untuk bekal hidup di masa sekarang dan masa akan datang. Menurut Anderson dalam Sukiman (2012) media pembelajaran adalah media yang memungkinkan terwujudnya interaksi langsung antara guru mata pelajaran dengan para siswa. Secara umum wajarlah bila peranan guru yang menggunakan media pembelajaran sangatlah berbeda dari peranan guru "biasa".

Menurut Levied an Lentz dalam Sukiman (2012) khususnya media visual, mengemukakan bahwa media pendidikan memiliki empat fungsi yaitu: fungsi atensi, fungsi afektif, fungsi kognitif, dan fungsi kompensatoris. Fungsi atensi media visual merupakan inti, yaitu mengerahkan perhatian peserta didik untuk fokus dan berkonstrasi kepada isi pembelajaran. Media gambar khusunya gambar yang diproyeksi melalui overhead proyektor (OHP) kemungkinan untuk memperoleh dan mengingat isi pelajaran semakin besar sehingga mengarahkan perhatian peserta didik kepada pelajaran yang akan mereka terima. Fungsi afektif media visual dapat terlihat dari tingkat kenikmatan peserta diidk ketika belajar (atau membaca) teks yang bergambar. Fungsi kognitif media yang berisi lambang-lambnag visual atau gambar dapat memperlancar pencapaian tujuan untuk memahami dan mnegingat informasi atau pesan yang terkandung pada apa yang dimpilkan oleh guru. Fungsi kompensatoris media visual yang memberi konteks untuk memahami teks membantu siswa yang lemah dalam membaca untuk mengorganisasikan informasi dalam teks dan mengingatnya kembali. 
Arief S. Sadiman dalam Sukiman, (2012) menyampaikan manfaat media pembelajaran secara umum sebagai berikut:

1. Memperjelas pesan agar tidak terlalu verbalitas.

2. Mengatasi keterbatasan ruang, waktu, dan daya indera.

3. Menimbulkan gairah belajar, meningkatkan motivasi belajar peseta didik.

4. Memberikan rangsangan yang sama, mempersamakan pengalaman dan menimbulkan persepsi yang sama kepada peserta didik.

5. Memungkinkan anak belajar mandiri sesuai dengan bakat dan kemampuan visual. Media pembelajaran memberikan manfaat secara langsung terhadap proses pembelajaran, dimana efek yang ditimbulkan dapat dirasakan langsung oleh peserta didik. Guru dapat melihat perkembangan belajar peserta didik berbeda sebelum dan sesudah menggunakan media pembelajaran.

Mutia Imtihana (2014) bahwa

media yang akan digunakan dalam pembelajaran harus memenuhi syarat visible, interesting, simple, useful, accurate, legitimate, structure (VISUALS):

1. Visible atau mudah dilihat, artinya media yang digunakan harus dapat memberikan keterbacaan bagi orang lain yang membacanya.

2. Interesting atau menarik, yaitu media yang digunakan harus memiliki nilai kemenarikan. Sehingga yang melihatnya akan tergerak dan terdorong untuk memperhatikan pesan yang disampaikan melalui media tersebut.

3. Simple atau sederhana, yaitu media yang digunakan harus memiliki nilai kepraktisan dan kesederhanaan, sehingga tidak berakibat pada inefisiensi dalam pembelajaran.

4. Useful atau bermanfaat, yaitu media yang akan digunakan dapat bermanfaat dalam pencapaian tujuan pembelajaran yang diharapkan.

5. Accurate atau benar, yaitu media yang dipilih benar sesuai dengan karakteristik materi atau tujuan pembelajaran, dengan kata lain media tersebut benar- benar valid dalam pembuatan dan penggunaannya dalam pembelajaran.

6. Legitimate atau sah, masuk akal artinya media pembelajaran dirancang dan digunakan untuk kepentingan pembelajaran oleh orang atau lembaga yang berwenang.

7. Structure atau terstruktur, artinya media pembelajaran, baik dalam pembuatan atau penggunaannya merupakan bagian 
tak terpisahkan dari materi yang akan

disampaikan melalui media tersebut.

Berdasarkan pemahaman di atas tentang pemilihan media pembelajaran bahwasanya, pemilihan media pembelajaran harus sesuai dengan tujuan pembelajaran yang ingin dicapai dan media yang digunakan harus mudah di pahami oleh siswa sehingga memungkinkan siswa dapat berinteraksi dengan media yang kita pilih dan pembelajaran lebih menarik perhatian sisswa sehingga dapat menumbuhkan motivasi belajar.

Berdasarkan kondisi dan pembahasan di atas, peneliti melakukan penelitian meta-analisis jenis Systemic review 10 jurnal nasional terakreditasi, dengan tujuan untuk menganalisis penggunaa media pembelajaran dalam meningkatkan kemampuan berpikir kreatif siswa.

\section{Metode}

Metode penelitian yang digunakan dalam penelitian ini adalah metode penelitian Meta- analisis, Meta-analisis menurut Kitchenham dalam Hasanah (2016) adalah salah satu jenis Systemic review. Systemic review adalah salah satu metode penelitian dokumen yang sistematis untuk mensintesis hasil-hasil penelitian dalam bentuk kegiatan mengidentifikasi, mengevaluasi dan menginterpretasi semua penelitian-penelitian relevan untuk sebuah pertanyaan penelitian khusus, atau area topik atau fenomena tertentu yang menjadi minat peneliti.

Penelitian meta-analisis disebut juga penelitian meta atau meta research. Penelitian ini menggunakan jurnal sebagai sumber datanya. Peneliti akan mengambil beberapa penelitian yang memiliki satu topik atau tema yang sama dalam penelitian ini. Metode ini digunakan untuk meringkas, merangkum dan memperoleh intisari hasil temuan dari sejumlah penelitian. Objek dalam penelitian ini adalah menggunakan 10 jurnal yang relevan yang di download dari situs jurnal ilimiah yang terakreditasi Sinta.

Analisis peningkatan kemampuan berpikir kretaif siswa menggunakan data selisih maka menggunakan rumus sebagai berikut:

selisih $=$ nilai terbesar - nilai terkecil.

dan untuk mengetahui berapa persen peningkatan hasil belajar maka menggunakan rumus sebagai berikut:

Persen $(\%)=\quad$ Jumlah X 100 Data awal Selisih 
Untuk mengetahui nilai rata-rata pada peningkatan kemampuan berpikir siswa maka digunakan rumus sebagai berikut:

$$
\text { Nilai rata-rata }=\underline{\text { Jumlah nilai }}
$$

\section{Hasil dan Pembahasan}

Hasil review 10 jurnal ilmiah dengan menggunakan metode metaanalisis.

1. Dian Sudiantini: Pengaruh media pembelajaran terhadap kemampuan berpikir kreatif dan penalaran matematis siswa.

Penelitian bertujun untuk mengetahui pengaruh media pembelajaran, yang menggunakan Power Point dan Konvensional, berpikir Kreatif tinggi dan rendah serta interaksi keduanya antara penggunaan media pembelajaran dan berpikir kreatif terhadap kemampuan penalaran matematika. Metode penelitian yang digunakan menggunakan metode eksperimen dengan menerapkan media pembelajaran yaitu media pembelajaran powerpoint. Subjek penelitian dibagi atas dua kelompok yaitu kelompok eksperimen dan kelompok control sebagai populasi seluruh siswa SD Muhammadiyah Cisalak di Kecamatan Sukmajaya Kota Depok dan sampel siswa kelas VI A sebagai kelas eksperimen dan kelas VI B sebagai kelas kontrol. Dari hasil penelitian diperoleh data dan selanjutnya dianalisis dengan bantuan SPSS untuk mengetahui pengaruh penggunaan media pembelajaran terhadap kemampuan berpikir kreatif siswa.

2. Latifatul Ariyani: Pengaruh model number head together (NHT) berbantu media monopoli untuk meningkatkan hasil belajar dan kemampuan berpikir kreatif siswa kelas IV sub tema hebatnya cita-citaku SDN Mbranggen 04.

Jenis penelitian ini adalah penelitian kuantitatif dalam bentuk Quasi Eksperimental dengan desain Nonequivalent Control Group Design. Tujuan yang hendak dicapai dalam penelitian ini adalah untuk mengetahui pengaruh model pembelajaran Numbered Heads Together (NHT). Populasi penelitian adalah seluruh siswa kelas IV SDN MRANGGEN 04 tahun pelajaran 2019. Sampel yang diambil adalah 41 siswa kelas IVA dan IVB teknik Probability Sampling berbentuk Cluster Sampling. Data dalam penelitian ini diperoleh melalui tes, wawancara, dokumentasi, dan observasi.

3. Calvin Talakua: Pengaruh Penggunaan Media Pembelajaran Biologi Berbasis 
Mobile Learning terhadap Minat dan Kemampuan Berpikir Kreatif Siswa SMA Kota Masohi. Penelitian ini bertujuan untuk mengetahui pengaruh penggunaan media pembelajaran biologi berbasis Mobile Learning terhadap minat belajar dan kemampuan berpikir kreatif siswa SMA di Kota Masohi. Penelitian ini termasuk quasi eksperiment dengan rancangan PretestPostest Non-Equivalent Control Group. Sampel penelitian adalah SMA Negeri 1 Masohi dan SMA Negeri 2 Masohi. Hasil penelitian menunjukkan bahwa ada pengaruh penggunaan media pembelajaran berbasis Mobile Learning terhadap minat belajar dan kemampuan berpikir kreatif siswa SMA di Kota Masohi.

4. Febriana Istiqomah: Pengaruh media kokami terhadap keterampilan berpikir kreatif dan aktivitas belajar tema bahan kimia.

Penelitian ini bertujuan untuk mengetahui pengaruh media kokami terhadap keterampilan berpikir kreatif dan aktivitas belajar tema bahan kimia. Penelitian ini merupakan penelitian eksperimen dengan jenis quasi experimental design. Penelitian dilaksanakan di SD Negeri 32 Semarang dengan subjek penelitian siswa kelas V.
5. Yanti Arasi Sidabutar: Pengaruh penggunaan media pembelajaran dan kemampuan berpikir kreatif terhadap kemampuan menulis narasi siswa kelas 5 SD Negeri 060841 Medan

Penelitian ini merupakan penelitian semu (quasi eksperimen). Populasi penelitian ini adalah siswa kelas V SD Negeri 060841. Sampel dalam penelitian ini dipilih secara total sampling sebanyak dua kelas. Kelas eksperimen diberikan perlakuan dengan menggunakan media gambar berseri dan kelas kontrol diberikan perlakuan menggunakan media lagu. Instrumen yang digunakan terdiri dari tes kemampuan menulis narasi dalam bentuk essay test dan lembar angket kemampuan berpikir kreatif siswa yang telah dinyatakan valid dan reliabel. Analisis data dilakukan dengan menggunakan ANAVA dua jalur.

6. Silvia Rahmawati: Pengaruh penggunaan media pembelajaran styprobon terhadap kreativitas berpikir dan hasil belajar kognitif

Penelitian ini bertujuan untuk mengetahui pengaruh penggunaan media pembelajaran styprobon terhadap kreativitas berpikir dan hasil belajar kognitif siswa. Penelitian ini merupakan penelitian eksperimen semu (Quasi experiment). Desain penelitian 
yang digunakan dalam penelitian ini adalah nonequivalent control group design atau pretest- posttest control group design. Populasi pada penelitian ini yaitu seluruh peserta didik kelas $\mathrm{V}$ SDN Bantul tahun ajaran 2017/2018.

7. Ading muslihudin: Pengaruh media CD interaksi terhadap keterampilan berpikir kreatif siswa dalam mata pelajaran ips.

Tujuan dari penelitian ini adalah untuk menguji pengaruh media CD interaktif dibandingkan dengan media konvensional terhadap keterampilan berpikir kreatif dalam mata pelajaran Ilmu Pengetahuan Sosial siswa kelas IV SD Negeri Cipicung Kabupaten Kuningan. Populasi dalam penelitian ini adalah seluruh siswa SD kelas IV dengan sampel penelitian siswa kelas IV. Metode penelitian yang digunakan adalah kuasi eksperimen dengan desain Pretest Posttest Control Group Design. Pengambilan sampel dilakukan dengan teknik purposive sampling.

8. Mohammad faizal Amir Pengembangan domino pecahan berbasis open ended untuk meningkatkan kemampuan berpikir kreatif siswa SD.

Jenis penelitian ini merupakan penelitian pengembangan digunakan berupa lembar validasi ahli media dan materi, lembar penilaian menggunakan model pengembangan plomp. Penerapan dilakukan dikelas VI SDN Kalitengah 1 Sidoarjo yang terdiri dari 40 siswa. Validasi desain produk dalam penelitian pengembangan dapat dilakukan melalui validasi oleh ahli.

9. Fauzi khoirul mahfi: Pengembangan game edutainment berbasis smartphone sebagai media pembelajaran berorentasi pada kemampuan berpikir kreatif.

Penelitian ini bertujuan untuk mendeskripsikan langkah pengembangan serta melihat kelayakan dari sebuah game edutainment berbasis smartphone yang digunakan sebagai media pembelajaran berorientasi pada kemampuan berpikir kreatif siswa. Jenis penelitian ini adalah penelitian pengembangan dengan prosedur pengembangannya menggunakan model ADDIE. Adapun prosedur pengembangannya terdiri dari analisis masalah, analisis materi, validasi kesenjangan kinerja, desain produk, validasi ahli media dan ahli materi, uji coba perorangan, uji coba kelompok, dan implementasi. Subjek dalam penelitian ini adalah siswa kelas VII SDN 1 Kota Jambi. Instrumen yang 
guru, lembar penilaian siswa, dan angket persepsi siswa, serta soal tes kemampuan berpikir kreatif.

10. Ela Latifatul Fajariyah: Penerapan Media Puzzle Untuk meningkatkan Hasil Belajar Siswa Mata Pelajaran Ips Kelas V SDN 01 Sumberrejo Kota gajah Tahun Pelajaran 2016/2017.

Tujuan penelitian ini adalah untuk meningkatkan penerapan media puzzle dalam meningkatkan hasil belajar siswa pada pembelajaran ips di kelas V SD N 1 Sumberrejo Kotagajah. Fakta itu, peneliti peroleh dari hasil post test yang peneliti lakukan pada pertemuan I, dimana diketahui rata-rata prosentase hasil belajar siswa hanya sebesar $33 \%$ atau hanya sekitar 10 siswa yang memiliki hasil belajar yang tinggi, sisanya sebanyak 20 siswa atau $65 \%$ termasuk kategori yang memiliki motivasi rendah. Dalam Penelitian Tindakan Kelas (PTK) ini, tindakan yang dimunculkan adalah "Penerapan Media Puzzle Untuk Meningkatkan Hasil Belajar Siswa Mata Pelajaran IPS Kelas V SDN 01 Sumberrejo Kotagajah Tahun Pelajaran 2016/2017." Alat pengumpul data, meliputi: observasi, test, dan dokumentasi. Dalam pelaksanaan tindakan, ditetapkan siklus I dan siklus II, yang meliputi tahapan 1). Rencana Tindakan, 2). Pelaksanaan Tindakan, 3). Pengamatan Tindakan, dan 4). Refleksi Tindakan.

Tabel 1. Hasil Peningkatan Kemampuan Berpikir Kreatif Siswa.

\begin{tabular}{|c|c|c|c|c|}
\hline No & Judul & $\begin{array}{c}\text { Peneliti dan } \\
\text { Tahun } \\
\text { Penelitian }\end{array}$ & $\begin{array}{l}\text { Nama } \\
\text { Jurnal }\end{array}$ & $\begin{array}{c}\text { Peningkatan Hasil } \\
\text { Belajar }\end{array}$ \\
\hline 1 & $\begin{array}{l}\text { Pengaruh media } \\
\text { pembelajaran terhadap } \\
\text { kemampuan berpikir } \\
\text { kreatif dan penalaran } \\
\text { matematis siswa }\end{array}$ & $\begin{array}{c}\text { Dian } \\
\text { Sudiantini } \\
(2018)\end{array}$ & $\begin{array}{c}\text { Journal } \\
\text { JPPM Vol. } \\
\text { 11 No. } 1 \\
\text { (2018) }\end{array}$ & 67,5 \\
\hline 2 & $\begin{array}{l}\text { Pengaruh model number } \\
\text { head together (NHT) } \\
\text { berbantu media monopoli } \\
\text { untuk meningkatkan hasil } \\
\text { belajar dan kemampuan } \\
\text { berpikir kreatif siswa } \\
\text { kelas IV sub tema } \\
\text { hebatnya cita-citaku SDN } \\
\text { Mbranggen } 04\end{array}$ & $\begin{array}{c}\text { Latifatul } \\
\text { Ariyani (2019) }\end{array}$ & $\begin{array}{c}\text { Jurnal } \\
\text { Mimbar } \\
\text { Ilmu, Vol. } \\
24 \text { No. 3, } \\
2019\end{array}$ & 77,55 \\
\hline
\end{tabular}




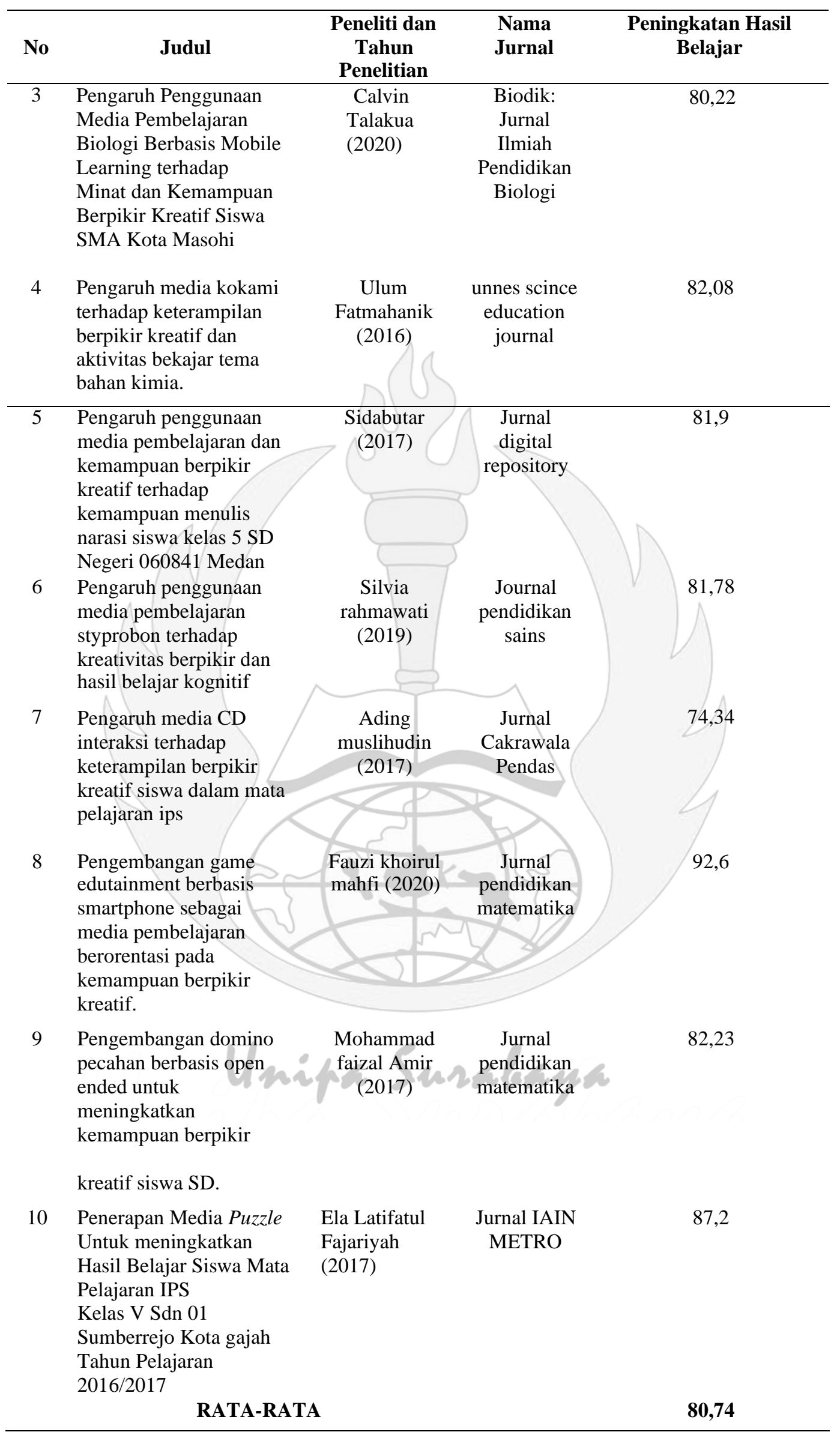


Berdasarkan analisis data dari 10 jurnal yang relevan di atas, dapat di ketahui bahwa penggunaan media pembelajaran dapat meningkatkan kemampuan berpikir kreatif siswa dengan total ketuntasan ratarata setelah menerapkan media pembelajaran mencapai $80,74 \%$. Hal ini membuktikan bahwa penggunaan media yang variatif pada saat proses pembelajaran dapat meningkatkan kemampuan berpikir kreatif siswa yang sangat signifikan.

Tabel 2 Hasil Analisis Penggunaan Media Pembelajaran Dalam Meningkatkan Kemampuan Berpikir Kreatif Siswa Menggunakan Metode Kuantitatif.

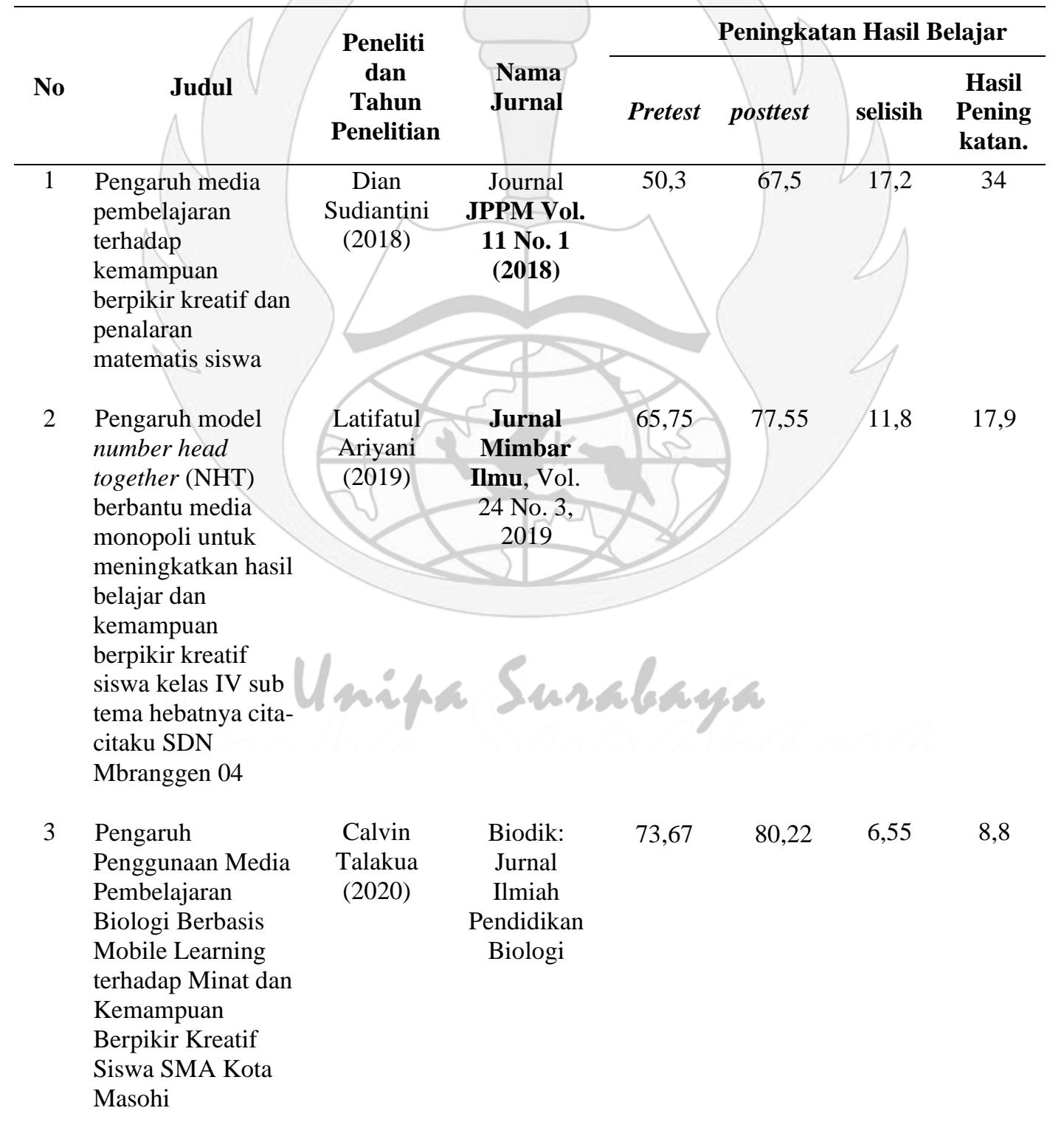



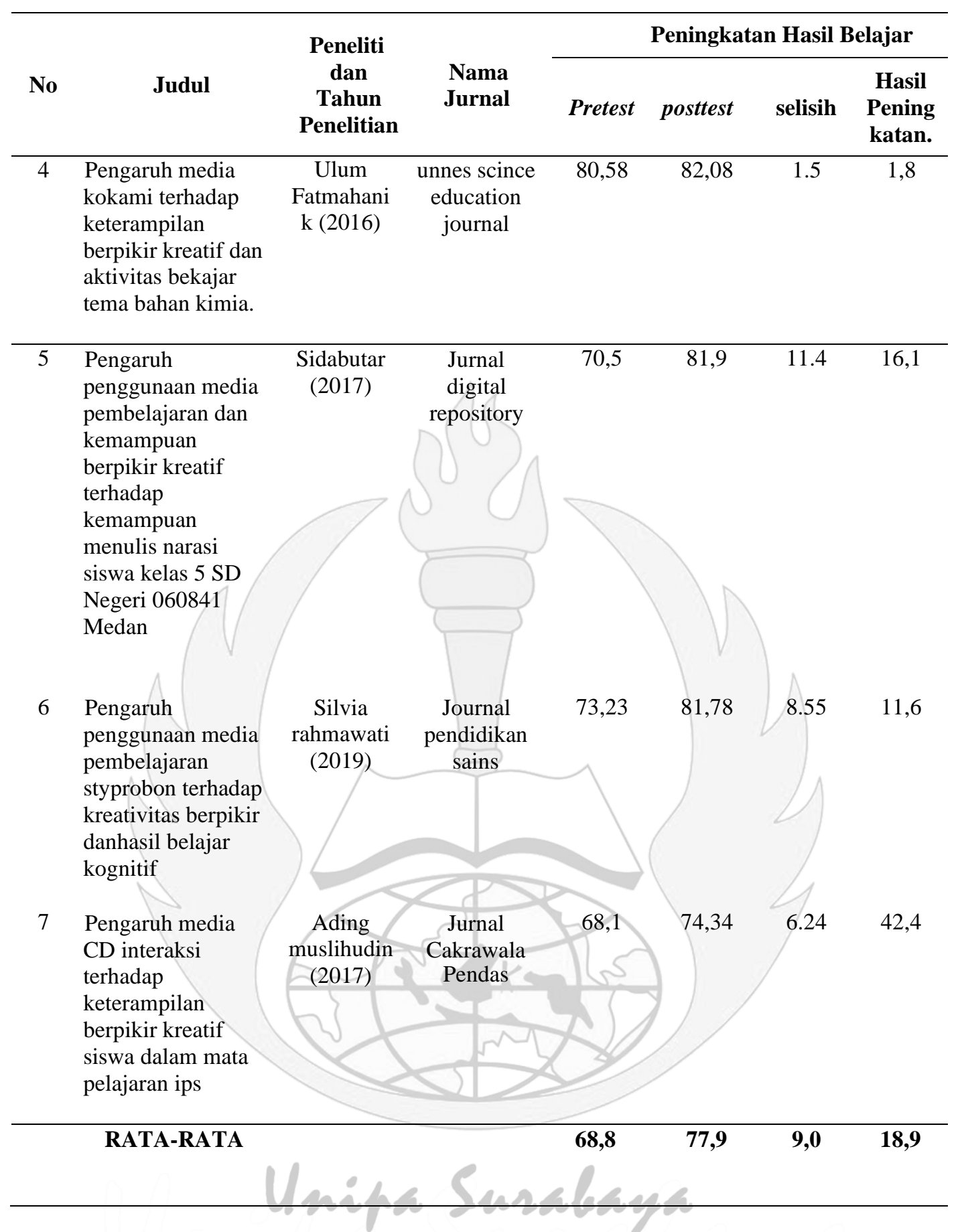

Berdasarkan data yang relevan diatas peneliti menganalisis tujuh data dari jurnal yang berbeda-beda namun dengan tujuan penelitian yang sama yaitu samasama bertujuan untuk meningkatkan kemampuan berpikir kreatif siswa dengan menggunakan media, dan metode yang digunakan oleh ke tujuh jurnal yaitu sama- sama menggunakan metode kuantitatif, berdasarkan analisis yang dilakukan oleh peneliti rata-rata hasil kemampuan berpikir kreatif siswa sebelum menggunakan media pembelajaran mencapai $68,8 \%$, sedangkan peningkatan hasil kemampuan berpikir kreatif siswa setelah penggunaan media pembelajaran mencapai $77.9 \%$. hal ini 
menunjukan bahwa penggunaan media

sangat efektif dalam meningkatkan

kemampuan berpikir kreatif siswa.

Tabel 3. Hasil Analisis penggunaan media pembelajaran dalam meningkatkan kemampuan berpikir kreatif siswa menggunakan metode Pengembangan

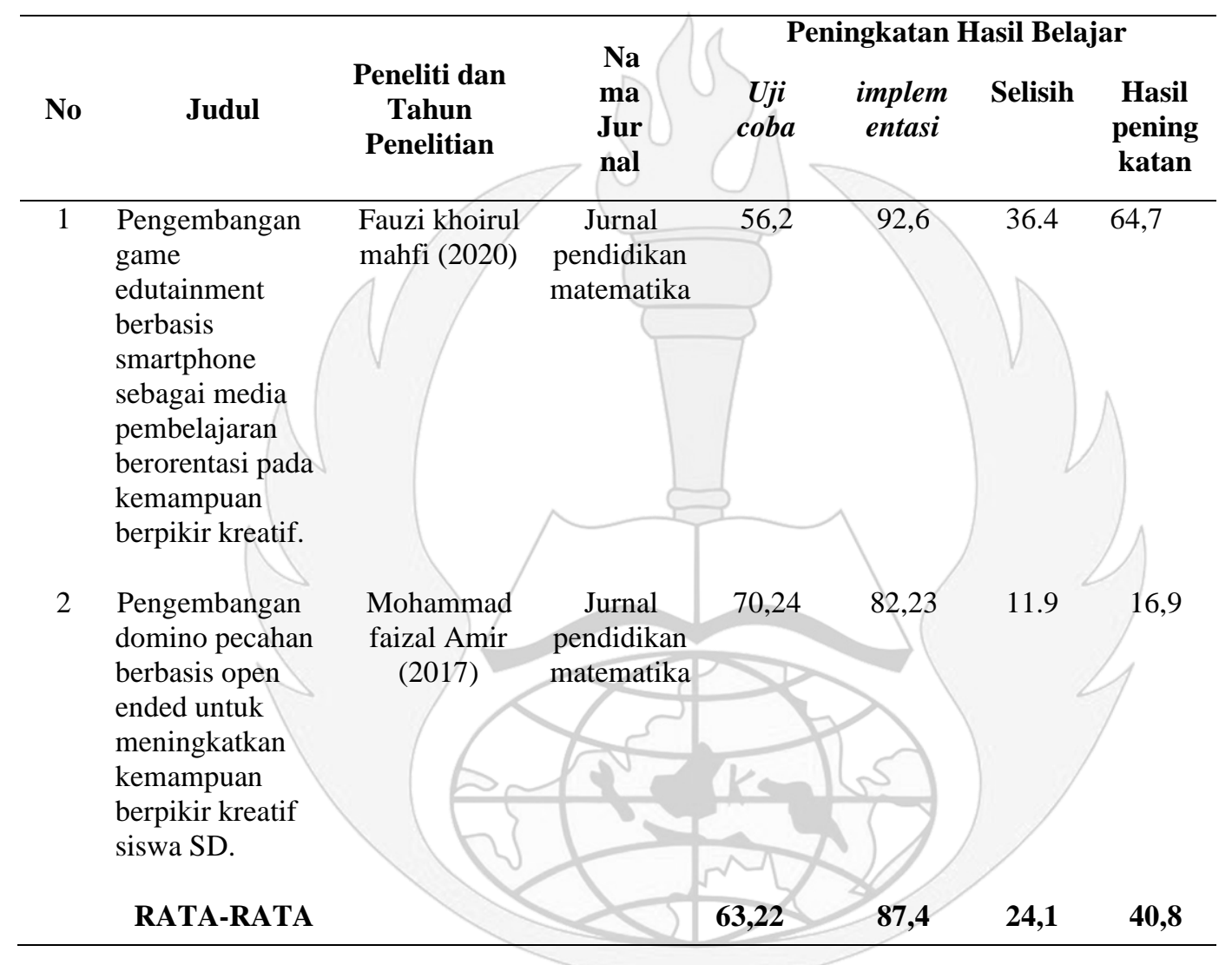

Berdasarkan data yang relevan di atas peneliti menganalisis dua data dari jurnal yang menggunakan metode pengembangan, hasil data yang diperoleh pada saat uji coba produk mencapai $63,22 \%$ dan pada saat implementasi produk hasil kemampuan berpikir kreatif siswa meningkat mencapai $87,4 \%$. Hal ini membuktikan bahwa media yang dikembangkan telah memenuhi kelayakan media yang valid, praktis dan efektif. Memenuhi kriteria kevalidan yang dilihat dari hasil validasi ahli media dan ahli materi. Untuk hasil validasi dariahli media diperoleh kesimpulan bahwa media sudah valid untuk digunakan. Hasil validaasi dari ahli materi menyatakan bahwa materi dalam media valid. 
Tabel 4. Hasil Analisis Penggunaan Media Pembelajaran Dalam Meningkatkan Kemampuan Berpikir Kreatif Siswa Menggunakan Metode PTK

\begin{tabular}{|c|c|c|c|c|c|c|c|}
\hline \multirow[b]{2}{*}{ No } & \multirow[b]{2}{*}{ Judul } & \multirow[b]{2}{*}{$\begin{array}{l}\text { Peneliti dan } \\
\text { Tahun } \\
\text { Penelitian }\end{array}$} & \multirow[b]{2}{*}{$\begin{array}{l}\text { Nama } \\
\text { Jurnal }\end{array}$} & \multicolumn{4}{|c|}{ Peningkatan Hasil Belajar } \\
\hline & & & & Siklus 1 & Siklus 2 & Selisih & $\begin{array}{c}\text { Hasil } \\
\text { Pening } \\
\text { Katan }\end{array}$ \\
\hline 1 & $\begin{array}{l}\text { Penerapan Media } \\
\text { Puzzle untuk } \\
\text { meningkatkan } \\
\text { Hasil Belajar } \\
\text { Siswa Mata } \\
\text { Pelajaran Ips Kelas } \\
\text { V Sdn 01 } \\
\text { Sumberrejo Kota } \\
\text { gajah Tahun } \\
\text { Pelajaran } \\
2016 / 2017\end{array}$ & $\begin{array}{l}\text { Ela Latifatul } \\
\text { Fajariyah } \\
\text { (2017) }\end{array}$ & $\begin{array}{c}\text { Jurnal } \\
\text { IAIN } \\
\text { METRO }\end{array}$ & 71.5 & 87,2 & 15,7 & 21,9 \\
\hline & RATA-RATA & & & 71,5 & 87,2 & 15,7 & 21,9 \\
\hline
\end{tabular}

Berdasarkan data yang relevan diatas peneliti menganalisis data dari jurnal yang menggunakan metode penelitian tindakan kelas (PTK). penggunaan media pembelajaran puzzle dapat meningkatkan kemampuan berpikir kreatif siswa. Pada siklus pertama kemampuan berpikir kreatif siswa adalah $71,5 \%$ sedangkan siklus kedua sebesar $87,2 \%$ sehingga peningkatan siklus pertama dan siklus kedua $15,7 \%$. Penggunaan media pembelajaran puzzle dapat meningkatkan kemampuan guru mengajar. Pada siklus pertama hingga siklus kedua yang terlihat sangat signifikan.

Berdasarkan analisis yang dilakukan oleh peneliti terhadap penelitian yang relevan diatas dengan menggunakan 10 jurnal mencapai hasil rata-rata yaitu $80,74 \%$, hal ini membuktikan bahwa penggunaan media pembelajaran dapat meningkatkan kemampuan berpikir kreatif siswa, namun terdapat perbedaan pada hasil peningkatan kemampuan berpikir kreatif siswa disetiap penelitian. Hal ini disebabkan oleh berbedaan objek penelitian, pendekatan, prinsip, dan konsep yang digunakan untuk menganalisis permasalahan pada penelitiannya berbeda, dan juga terlihat dari 10 jurnal tersebut menggunakan metode penelitian yang berbeda misalnya, menggunakan, metode kuantitatif, pengembangan, dan juga penelitian tindakan kelas (PTK).

Pembelajaran menggunakan media sangatlah penting untuk meningkatkan kemampuan berpikir kreatif siswa dan menghindari terjadinya pembelajaran yang monoton sehingga pembelajaran cenderung bersifat membosankan. Adanya media 
pembelajaran dapat menarik perhatian siswa dalam menyelesaikan suatu permasalahan. hal ini sejalan dengan Pendapat Mc Kenzie dalam Musfiqon, (2012). Media pembelajaran merupakan salah satu faktor yang mempengaruhi hasil belajar. Media pembelajaran telah menjadi bagian integral dari pembelajaran. Bahkan keberadaanya tidak bisa dipisahkan dalam proses pembelajaran di sekolah. Hal ini telah dikaji dan diteliti bahwa pembelajaran yang menggunakan media hasilnya lebih optimal.

\section{Kesimpulan}

Berdasarkan analisis dan pembahasan yang telah dilakukan diatas melalui review 10 jurnal dapat disimpulkan bahwa penggunaan media dapat meningkatkan kemampuan berpikir kreatif siswa dengan total presentase mencapai $80,74 \%$. Berdasarkan analisis yang dilakukan oleh peneliti terhadap penelitian yang relevan diatas terdapat perbedaan hasil peningkatan kemampuan berpikir kreatif siswa disetiap penelitian. Hal ini disebabkan berbedaan objek penelitian, pendekatan, prinsip, dan konsep yang digunakan untuk menganalisis permasalahan penelitiannya berbeda

Penggunaan media harus sesuai dengan kondisi siswa, sehingga memberikan pengalaman belajar yang menyenangkan dan disamping itu siswa dapat berpikir kreatif dalam memecahkan masalah yang terjadi.
Diharapkan guru dapat mengetahui pentingnya penggunaan media dalam proses pembelajaran sehingga guru dapat mengetahui kemampuan berpikir kreatif siswa dalam belajar dan guru akan lebih kreatif dan variatif dalam menggunakan media saat proses pembelajaran. Dan bagi peneliti selanjutnya diharapkan untuk mengkaji lebih banyak sumber maupun referensi yang terkait dengan penggunaan media pembelajaran dalam meningkatkan kemampuan berpikir kreatif siswa agar penelitiannya lebih baik lagi.

\section{Daftar Pustaka}

Afiani, K. D. (2017). Peningkatan Kemampuan Berpikir Kreatif Pada Siswa Kelas III SD Melalui Pembelajaran Berbasis Pengajuan Masalah. ELSE (Elementeri School Education Journal).

Amir, M. F. (2017). Pengembangan Domino Pecahan Berbasis Open Ended Untuk Meningkatkan Kemampuan Berpikir Kreatif Siswa SD. Jurnal Pendidikan Matematika.

Fajariyah latifatul E. (2017). Penerapan Media Puzzle Untuk meningkatkan Hasil Belajar Siswa Mata Pelajaran Ips Kelas V Sdn 01 Sumberrejo. Jurnal iain metro.

Hanik, U. F. (2016). Pengaruh Media Kokami Terhadap Keterampilan Berpikir Kreatif Dan Aktivitas Bekajar Tema Bahan Kimia. Uness Saince Education Journal.

Hasanah. (2016). Meta-Analisis Kualitatif Berbasis Inkuiri. Unnes. 
Imtihana. (2014). Pengembangan Buket Berbasis Penelitian Sebagai Sumber. Unnes Journal Of Biologt Education.

Indriani. (2014). Pembelajaran Berbasis Masalah Berbantu Autograph Untuk Meningkatkan Kemampuan Berpikir Kreatif Matematika Siswa . Repository.Upi.Edu

Latifatul. (2019). Pengaruh Model Number Head Together (NHT) Berbantu Media Monopoli Untuk Meningkatkan Hasil Belajar Dan Kemampuan Berpikir Kreatif Siswa Kelas IV Sub Tema Hebatnya Cita-Citaku SDN Mbranggen 04. Mimbar Ilmu.

Mahfi, F. K. (2020). Pengembangan Game Edutainment Berbasis Smartphone Sebagai Media Pembelajaran Berorentasi Pada Kemampuan Berpikir Kreatif. Jurnal Pendidikan Matematika.

Musfiqon. (2012). Pengembangan Media Dan Sumber Pembelajaran. Jakarta: Prestasi Pustaka Publishet.

Muslihudin, A. (2017). Pengaruh Media CD Interaksi Terhadap Keterampilan Berpikir Kreatif Siswa Dalam Mata Pelajaran Ips. Cakrawala Pendas.

Rahmawati, S. (2019). Pengaruh Penggunaan Media Pembelajaran Styprobon Terhadap Kreativitas Berpikir Dan Hasil Belajar Kognitif. Journal Pendidikan Sains.
Sidabutar. (2017). Pengaruh Penggunaan Media Pembelajaran Dan Kemampuan Berpikir Kreatif Terhadap Kemampuan Menulis Narasi Siswa Kelas 5 SD Negeri 060841 Medan. Jurnal Digital Repository.

Sudiyantini, D. (2018). Pengaruh Media Pembelajaran Terhadap Kemampuan Berpikir Kreatif Dan Penalaran Matematis Siwa. JPPM Vol 11.

Sukiman. (2012). Pengembangan Media Pembelajaran. Yogyakarta: Pedagogia. Sugiyono. (2010). Metode Penelitian Kuantitatif, Kualitatif, Dan $R \& D$. Bandung: Alfabeta.

Siswono. (2008). Model Pembelajaran Matematika Berbasis Pangajuan Masalah Dan Pemecahan Masalah Untuk Meningkatkan Kemampuan Berpikir Kreatif. Surabaya: Unesa University Press

Talakua C. (2020). Pengaruh Penggunaan Media Pembelajaran Biologi Berbasis Mobile Learning Terhadap Minat Dan Kemampuan Berpikir Kreatif Siswa SMA Kota Masohi. Biodik: Jurnal Ilmiah Pendidikan Biologi.

Zainiyati, H. S. (2017). Pengembangan Media Pembelajaran Berbasis ICT Konsep Dan Aplikasi Pada Pembelajaran Pendidikan Agama Islam. Jakarta: Kencana 